\title{
Technika mówienia a kompetencje językowo-komunikacyjne nauczyciela i ucznia
}

DOI: http://dx.doi.org/10.12775/LC.2016.010

Streszczenie. Tekst zwraca uwagę na komunikację werbalną, w tym nie tylko logikę czy estetykę, ale również technikę mówienia - nieco zaniedbywaną w szkolnej edukacji. Przywołane dokumenty programujące nauczanie na różnych etapach kształcenia oraz praktyczne podpowiedzi dowodzą potrzeby i konieczności pracy nad komunikacją werbalną uczniów.

Słowa kluczowe: komunikacja językowa; technika mówienia; kompetencja językowa; kompetencja komunikacyjna

\section{Summary}

The technique of speaking: verbal and communicational competences of teacher and student

The article pays attention to verbal communication, including not only the logic or esthetics, but also the technique of speaking - somewhat neglected in school education. Quoted documents of programming teaching at various stages of education as well as practical tips, show the need and necessity of working on students' verbal communication.

Keywords: linguistic communication; speaking technique; language competence; communication competence

* Doktor, adiunkt w Katedrze Dialektologii Polskiej i Logopedii w Instytucie Filologii Polskiej Uniwersytetu Łódzkiego. Obecnie zainteresowania badawcze koncentruje m.in. wokół wpływu przemian kulturowych na edukację i komunikację interpersonalną, kultury żywego słowa, emisji i higieny głosu oraz techniki mówienia. E-mail: kazmierczakmonika@o2.pl 
Czyż nie jest więc rzeczą nieodzownie konieczną, ażeby każdy człowiek inteligentny, a zwłaszcza obywatel z ukończoną szkołą średnią lub wyższą, mówił i czytał na głos co najmniej tak, ażeby go słyszano i rozumiano?! Juliusz Tenner

ożna się zastanawiać, czy we współczesnym świecie przeżywamy renesans retoryki i obserwujemy potrzebę ponownego odkrycia komunikacji ustnej ${ }^{2}$; wiadomo na pewno, że uczniowie decydujący się na przystąpienie do egzaminu maturalnego są zobowiązani do zaprezentowania przygotowanego w ciągu 15 minut wystąpienia - monologu na temat wskazany w arkuszu, a następnie krótkiej rozmowy z komisją wokół jednego zagadnienia odnoszącego się do prezentacji. Homo rhetoricus zdarza się na egzaminach sporadycznie, ale nie oznacza to, że do ideału nie należy dążyć, nawet jeśli w większości wypadków sukces będzie częściowy, a uczeń wykaże się lepszym opanowaniem kodów współtworzących wypowiedź (kinezyczno-proksemicznych) niż kodu językowego. Zachowania pozawerbalne uzupełniają znaczenia słów, a sukces na egzaminie będzie gwarantowany spójnym połączeniem działań werbalnych, suprasegmentalnych i niewerbalnych, tj. intencji, treści, sposobu tworzenia oraz przedstawiania wypowiedzi.

Egzamin maturalny jest zinstytucjonalizowany i zdeterminowany oficjalnym kontaktem nierównorzędnych rozmówców. Wcześniejsze przygotowanie wystąpienia, krótkie przemyślenie warstwy syntaktycznej i leksykalnej sprawia, że o większej (ograniczonej) spontaniczności można mówić w odniesieniu do rozmowy. Stosowany podczas egzaminu jej wariant oficjalny także cechuje duże sformalizowanie oraz skodyfikowanie językowych i pozajęzykowych zachowań grzecznościowych. W każdej z dwóch części interlokutorzy, mający świadomość oficjalnego charakteru kontaktu, starają się mówić poprawnie, respektując normy językowe i wymawianiowe oraz bacząc na odpowiedni dobór warstwy leksykalnej. „Nie należy dbać o to, o czym się mówi, lecz jak się mówi” - twierdził Demetrios, podkreślając pozytywny aspekt doskonalenia artykulacyjnego. W świetle ustnego egzaminu maturalnego z języka polskiego można by sparafrazować słowa greckiego retora i stwierdzić: „Nie należy dbać tylko o to, o czym się mówi, lecz również jak się mówi”.

Równie istotna jak zawartość merytoryczna jest formalna strona prezentacji. Kultura żywego słowa to bowiem środek działalności społecznej, gdyż z jednej strony prowadzi do świadomego wykorzystywania języka jako narzędzia komunikacji interpersonalnej, z drugiej zaś również stanowi jej cel - ponieważ podnosi poziom kultury człowieka ${ }^{3}$. Wszystkich polonistów obowiązuje przygotowanie ucznia do egzaminu maturalnego, podczas którego

\footnotetext{
1 J. Tenner, Technika żywego słowa, wyd. 3, Lwów 1931, s. 7.

2 Teza B. Bogołębskiej z artykułu Wygłaszanie przemówień w ujęciu współczesnych retoryk praktycznych, umieszczonego w tomie Problematyka tekstu głosowo interpretowanego, red. K. Lange, W. Sawrycki i P. Tański, Toruń 2004, s. 330.

3 J. Kram, Zarys kultury żywego słowa, Warszawa 1995, s. 19.
} 
są sprawdzane: meritum wypowiedzi monologowej - 40\% (16 pkt.), organizacja wypowiedzi monologowej - 20\% (8 pkt.), język i styl wypowiedzi monologowej i dialogowej - 20\% (8 pkt.), meritum wypowiedzi dialogowej i przestrzeganie zasad uczestniczenia w rozmowie $-20 \%$ (8 pkt.). W sumie za egzamin w części ustnej można uzyskać maksymalnie 40 punktów ${ }^{4}$. Dość często, przygotowując wypowiedź, maturzysta skupia się na treści, niesłusznie bagatelizując fleksję, składnię, frazeologię, komunikatywność stylu czy etykietę językową; nierzadko zupełnie ignoruje ortofonię.

Ortofonia, zajmująca się formułowaniem zasad poprawnej wymowy i poprawnego brzmienia wyrazów oraz ich połączeń w danym językư ${ }^{5}$, jest jednym z elementów ortoepii, stanowiącej dział językoznawstwa normatywnego, a obejmującej kwestie poprawnego używania języka. Do podstawowych składników poprawnej wymowy zalicza się: prawidłowe oddychanie, czystą tonację, wyraźną artykulację, związaną z prawidłową pracą narządów artykulacyjnych, co więcej - właściwe frazowanie, akcentowanie i intonację. Od czasu ogłoszonych w 1930 roku zasad poprawnej wymowy istnieją pojęcia starannej i potocznej polszczyzny. Technika mowy odnosi się do wariantu starannego, u którego podstaw leży „świadome dostosowanie sposobu wymawiania wyrazów do zasad poprawnej wymowy”, prowadzące do „skrupulatnego pozbycia się wszystkich naleciałości i niedbałości mowy potocznej”. Warunki skutecznej komunikacji podpowiadają, jak pracować nad warstwą foniczną, by wypowiedź była nie tylko zrozumiana (logika mówienia, stosowanie odpowiedniej prozodii, tempa, frazowania, akcentowania) oraz chętnie słuchana (estetyka mówienia), ale także słyszana (technika mówienia). Technika mówienia zwraca zatem uwagę na kilka innych technik: oddychania, prowadzenia głosu (emisja oracjalna), technikę artykulacyjną w zakresie poprawności (znajomość norm ortofonicznych, nawyk stosowania się do nich) oraz sprawność artykulacyjną (wyćwiczenie artykulatorów).

Cele dotyczące komunikacji werbalnej zostały zapisane w Rozporządzeniu Ministra Edukacji Narodowej z 30 maja 2014 roku (Dz. U. poz. 803). Już Podstawa programowa wychowania przedszkolnego (zał. 1, pkt 3) zwraca uwagę na wspomaganie rozwoju mowy oraz umiejętności komunikacyjnych ucznia, w tym: zrozumiałe i płynne mówienie, dostosowane natężenia i tonu głosu do konsytuacji, bezpośredni kontakt z rozmówcą, poprawność językową (artykulacyjną, gramatyczną, fleksyjną, składniową), stosowanie pozawerbalnych form komunikacji, uważne słuchanie, umiejętność zadawania pytań. Na zautomatyzowane, a także świadome posługiwanie się językiem wskazuje podstawa dla szkół podstawowych (zał. 2). Dokument wymaga, by w toku edukacji wczesnoszkolnej uczyć poprawnego i swobodnego posługiwania się językiem ojczystym, skutecznego porozumiewania, stopniowo przygotowywać do wystąpień publicznych oraz tworzyć warunki dla rozwoju wyobraźni i ekspresji werbalnej ${ }^{8}$. Podczas nabywania świadomości języka jako wielofunkcyjnego na-

\footnotetext{
4 Informator o egzaminie maturalnym z języka polskiego od roku szkolnego 2014/2015, s. 14, www.cke.edu.pl/ files/file/Matura-2015/Informatory-2015/Jezyk-polski.pdf [dostęp: 14.05.2015].

5 Dostępne są na rynku: Słownik wymowy polskiej, red. M. Karaś, M. Madejowa, Kraków 1977; W. Lubaś, S. Urbańczyk, Podręczny słownik poprawnej wymowy polskiej, Warszawa 1990.

6 P. Bąk, Gramatyka języka polskiego, Warszawa 1984, s. 100.

7 J. Tenner, op. cit., s. 164.

8 Uczeń kończący klasę III tworzy wypowiedzi: „a) w formie ustnej [...], b) dobiera właściwe formy komunikowania się w różnych sytuacjach społecznych, c) uczestniczy w rozmowach [...], d) dba o kulturę wypowiadania się; poprawnie artykułuje głoski, akcentuje wyrazy, stosuje pauzy i właściwą intonację w zdaniu [...]; stosuje formuły grzecznościowe, e) dostrzega różnicę pomiędzy literą i głoską; dzieli wyrazy na sylaby; oddziela wyrazy w zdaniu, zdania w tekście" (Dz. U. poz. 803, pkt. 3).
} 
rzędzia komunikacji uczniowie (także nauczyciele) nie mogą zapominać o kluczowej zasadzie: podstawą dobrego mówienia jest prawidłowe, intencjonalne oddychanie, wymagające spokoju, pewności siebie i opanowania tremy.

Werbalny system komunikowania, a w głównej mierze jego oralność, stanowi prymarny wyznacznik rozmowy, która dla dzieci z wrodzoną skłonnością do mówienia jest czymś naturalnym, podobnie jak ekspiracja. Na etapie przedszkolnym i wczesnoszkolnym łatwo prowadzić ćwiczenia oddechowe $\mathrm{w}$ formie zabawy, poprzedzającej świadome nabywanie kompetencji fonologicznej, czy szerzej - językowej ${ }^{9}$. Ważne, by już na wczesnym etapie wpajać podstawowe zasady stosowania oddechu mownego - chociażby ekonomii czy estetyki ${ }^{10}$. W szkole podstawowej ćwiczenia fonacyjno-oddechowe częściej występują podczas zajęć muzycznych niż lekcji języka polskiego; z czasem i taka forma zanika. Dlatego poloniści nie mogą zapominać, że przygotowanie ucznia do wystąpień publicznych należy rozpocząć od opanowania pełnego i racjonalnego oddychania, od wyrobienia długiej fazy wydechowej, stosowania równomiernej siły wydechu, ekonomicznego wydatkowania powietrza oraz od zsynchronizowania pauz oddechowych z treścią wypowiedzi - które stwarzają optymalne możliwości głosowe i przeciwdziałają zmęczeniu ${ }^{11}$.

Doskonalenie kompetencji komunikacyjnych w szkołach podstawowych wymaga wprowadzania wiadomości dotyczących systemu językowego oraz nowych umiejętności: rozwijania zainteresowania ucznia językiem ojczystym, świadomego i refleksyjnego jego używania, zwrócenia uwagi na różnorodne uwarunkowania aktów mowy, specyfikę illokucji i perlokucji, także wpływ suprasegmentaliów na charakter wypowiedzi - która powinna być płynna, poprawna artykulacyjnie oraz dykcyjnie ${ }^{12}$, właściwie akcentowana i intonowana, utrzymana w odpowiednim tempie. Wynika z tego, że wymagana w szkole znajomość leksyki, gramatyki, jak również niewerbalnych środków komunikacji (gest, mimika, postawa ciała itp.) - wspólnie tworzą podstawy dla oracji, dostosowanej do celu wypowiedzi oraz stwarzanych przez nauczyciela sytuacji, z czasem o charakterze bardziej oficjalnym. Podczas pracy z tekstem w szkołach ponadpodstawowych można oprzeć się na zalecanych do analizy tematach dotyczących mówionej odmiany języka, świadomości językowej, norm ortofonicznych bądź językowego savoir-vivre’u. Należy piętnować tzw. niechlujstwo językowe, co stanowi conditio sine qua non doskonalenia poprawnej wymowy i dobrego mówienia: „Aby «język giętki powiedział wszystko, co pomyśli głowa», ta właśnie «głowa» (rozum, wiedza, świadomość) też powinna być uodporniona na łatwizny, niechlujstwo,

\footnotetext{
9 Propozycje ćwiczeń są dostępne w bogatej literaturze logopedycznej, np. L. Kaczmarek, Nasze dziecko uczy się mowy, Lublin 1977; G. Demel, Minimum logopedyczne nauczyciela przedszkola, Warszawa 1998; B. Dittfeld, Spróbujmy mówić razem. Program profilaktyki logopedycznej (dla przedszkoli, klas kształcenia zintegrowanego i integracyjnego), Kraków 2006; D. Kamińska, Wspomaganie płynności mowy dziecka - profilaktyka, diagnoza i terapia jąkania wczesnodziecięcego, Kraków 2007.

10 Szerzej: J. Kram, op. cit., s. 30-31.

11 Por.: M. Schirner, Techniki oddychania. Techniki wydłużajace oddech (i życie), tłum. M. Dziedzic, Katowice 2003; L. Orr, Świadomy oddech, tłum. F. Tarnawski, K. Czubaj, Łódź 2006.

12 Ponieważ zdarza się wymienne używanie terminów dykcja i artykulacja, trzeba uściślić, iż artykulacja to „przekształcanie dźwięku tworzonego w jamie krtaniowej na zrozumiałą mowę” (Z. i H. Szletyńscy, Prawidłowe mówienie, Warszawa 1975, s. 41), zaś dykcja - „sposób wypowiadania się ukierunkowany znajomością norm i zasad szeroko rozumianej kultury żywego słowa” (J. Kram, op. cit., s. 19). Ex definitione dykcja jest pojęciem szerszym, a jedna z jej składowych to właśnie artykulacja.
} 
bełkotliwość języka potocznego. Niech więc [...] USZY - jak chce tego Cycero - «będą sędziami dźwięków»"13.

Uchybienia normie w mowie potocznej nie są rzadkie; najczęściej obserwuje się: nieczyste wymawianie głosek, zlewanie rozziewów, unikanie asymilacji dwóch brzmień podobnych, przeciąganie końcowych spółgłosek na początkowe samogłoski wyrazu następnego ([gńe-vioca], [pen-dovec]), połykanie głosek i sylab czy embolofazje. W pracy nad kompetencjami uczniów jedną z zasadniczych kwestii jest wiek mówiącego. U nastolatków obserwuje się pewne maniery wymawianiowe. Chłopcy mają tendencję do tubalnego mówienia, co wiąże się z mutacją. U dziewcząt bardzo często obserwuje się tzw. memiczną, czyli kozią emisję (okrągłe a o u wymawiają przy układzie warg zbliżonym do $e$ y i); niektórzy psycholodzy tłumaczą to infantylnym zachowaniem, wdzięczeniem się i nieustającym uśmiechaniem do otoczenia. Poza spłaszczoną wymową samogłosek nierzadko dochodzi do obniżenia artykulacyjnego i niestarannej wymowy wyrazów (np. [maue] zamiast [mauny], [v́iza] w miejsce [v́ize], [papraše] zamiast [poproše]). Bardzo często błędy ortofoniczne pojawiają się przy wymowie samogłosek nosowych na końcu wyrazów. Dwa najczęstsze to rozkładanie zachowującej nosowość $Q$ w końcówkach czasowników 3 os. 1. mn. ([idom], [ńosom] zamiast [idǫ], [ńoso]), a także doliterowe wymawianie ę, wyjątkowo rażące w wygłosie.

W wypadku grup spółgłoskowych często dochodzi do deformacji lub daleko idących fonetycznych redukcji, charakterystycznych dla mowy niestarannej czy gwar. Dla przykładu, w grupach: trz-, drz- i wyrazach typu: drzwi, drzewo, Andrzej, patrz, trzy, trzeba zębowe $t, d$ pod wpływem głosek dziąsłowych wymawia się również dziąsłowo: [ḍžv́i], [ḍževo], [anḍžei], [pațš], [ț̌y], [țšeba], ewentualnie następuje przejście - dopuszczane

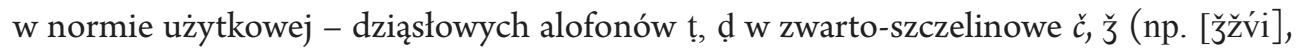

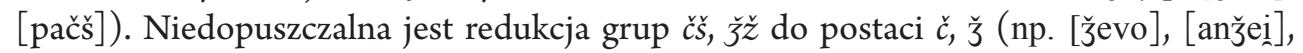
[čeba]), naruszającej normy ortofoniczne, choć spotykana np. w wymowie krakowskiej. Za niestaranność uważa się również zanik głoski sonornej w trudniejszych sekwencjach: w pozycji między spółgłoskami (np. [iapko], [ṕoska]), między samogłoskami (np. [bya],

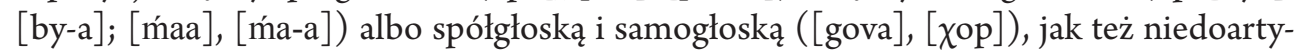
kułowanie wygłosu ([umys], [muk], [ṕis], [ṕeś], [v́at]), związane z dominującym w języku polskim akcentem paroksytonicznym, w efekcie którego końcówka wyrazu znajduje się w pozycji słabej. Staranna wymowa powinna oddawać pełne brzmienie $u$ w pozycji

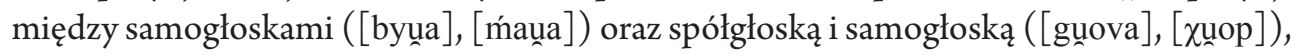
a także niewielki składnik szmerowy półsamogłosek i sonornych w pozycji między bezdźwięcznymi ([iapuko], [ṕosṇka]) oraz przed pauzą ([umysu], [muku]], [ṕism]], [ṕeśń], [v́atṛ]), zgodnie z zasadą słyszalności wygłosu, gdyż - jak pisał Norwid - „kto krementu czytać nie umie, nie wygłasza piękności słowa”.

Uwagę zwraca również artykulacja głosek wargowych miękkich. Przyjęto, iż wzorcowo należy je wymawiać w sposób synchroniczny (np. [ṕasek], [b́auny]), mimo iż zalecenia te są opozycyjne wobec tendencji mówienia uczniów i najnowszych badań, według których w języku ogólnym dominuje asynchroniczna wymowa z elementem palatalnym w postaci joty ([p'iasek], [b'iaun]]). Jednak w wyniku zbyt dużej asynchronii może dojść do niepożądanego i naruszającego normy ortofoniczne zjawiska epentezy, występującego

13 B. Toczyska, Kama makaka ma!, Warszawa 1994, s. 75. 


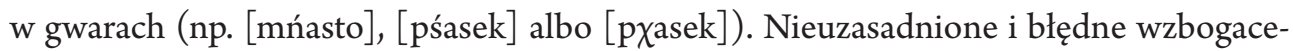
nie struktury wyrazu o dodatkowy fonem obserwuje się w mowie potocznej także przy sztucznym wzmacnianiu brzmienia spółgłosek przed półotwartą $r$ w wyrazach typu: $d r g a$, środa - wówczas słychać wyraźny pogłos samogłoskowy: [dyrga] lub [derga], [śiroda].

W codziennych wypowiedziach nauczyciel może również kontrolować koartykulację uczniów. Trzeba pamiętać o upodobnieniach międzywyrazowych (bez sztucznego udźwięczniania lub ubezdźwięczniania) oraz zasadach dotyczących zbiegów spółgłoskowych wewnątrzwyrazowych (zalecane przedłużenie momentu zwarcia - redukcja jednej

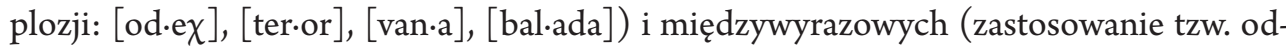
bitki artykulacyjnej i wzmocnienie ostatniej głoski pierwszego wyrazu: [nad domem], [pan naš], [maš šalik]). W fonetyce międzywyrazowej, kiedy drugi wyraz rozpoczyna się od sonornej bądź samogłoski, są dopuszczalne dwa warianty: udźwięcznianie, zgodnie z wymową południowo-zachodnich rejonów kraju, tzw. poznańską ([brad mamy], [vuz antka]) albo nieudźwięcznianie, zgodnie z wymową północno-wschodnich rejonów ([brat mamy], [vus antka]). To mazowieckie nieudźwięcznianie szerzy się na inne dialekty i jest zalecane w starannej odmianie polszczyzny mówionej, ale poprawianie osobniczej cechy wymowy będzie również nieprawidłowe. W przypadku rozziewu samogłoskowego

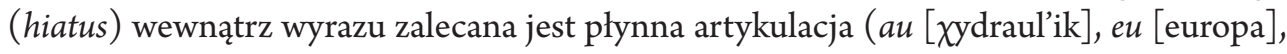

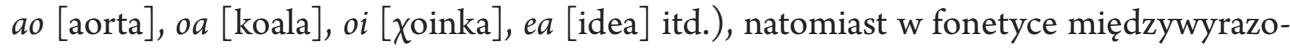
wej - odbitka artykulacyjna i wzmocnienie pierwszej głoski następnika (np. [to okno], [ta ąfora], [u ańi]). W wyrazach o trudnych połączeniach samogłoskowych czasem dochodzi do metatezy (np. [areoplan] zamiast [aeroplan], [areobik] zamiast [aerobik]) lub epentezy (np. [ideia] zamiast [idea], [kakauno] zamiast [kakao]), w efekcie których są tworzone formy niepoprawne, ale wymagające mniejszego wysiłku artykulacyjnego.

Dobre mówienie to nie tylko poprawna artykulacja, ważne, by melodię wyobrażoną podczas cichego czytania lub mówienia w myślach zrealizować głosowo, co pozwoli usłyszeć swą interpretację w celu jej weryfikacji. „Zasady poprawnego wymawiania streszczają się zatem, jak widzimy, w trzech momentach: 1) czyste wytworzenie dźwięków poszczególnych wedle ich znaczenia; 2) łączenie dźwięków w organiczną całość zgłoski; 3) wiązanie zgłosek energią akcentu samorodnego w wyższe jednostki wyrazów. Nauka o akcentach łączy się zatem organicznie z nauką wymawiania, czyli artykulacji”"14 - podkreślał teoretyk deklamacji, Juliusz Tenner. Teoretyczna refleksja w praktyce szkolnej, podobnie jak właściwa głosowa realizacja rytmiczno-melodyczno-akcentowa, warunkuje prawidłowe zrozumienie sensu wypowiedzi przez audytorium. „Na głos - ma to znaczyć: ze wszystkimi malowaniami, wygięciami, zwrotami tonu i zmianami tempa [... $]^{15}$ - czyli poza błędami w artykulacji trzeba niwelować u uczniów nieprawidłowości w zakresie intonacji, frazowania, przestankowania, modulacji głosu oraz akcentu, który przez Tennera został nazwany „uduchowieniem żywej mowy”. Do najczęstszych błędów i uchybień należą: niezgodna z normami transakcentacja w mowie spontanicznej, mało wyraźne używanie lub brak akcentów logicznego, ekspiracyjnego bądź symbolicznego ${ }^{16}$, nieprawidłowe członowanie tekstu oraz przestankowanie słuchowe bez użycia właściwych pauz (logicz-

\footnotetext{
4 J. Tenner, op. cit., s. 159.

15 K. Wóycicki, Forma dźwiękowa prozy polskiej i wiersza polskiego, Warszawa 1960, s. 15.

16 Por. M. Mikuta, Kultura żywego słowa, Warszawa 1963, s. 108; J. Kram, op. cit., s. 63-85.
} 
nych, składniowo-logicznych) i akcentów emocjonalnych, właściwej linii tonalnej czy odpowiedniej siły głosu w czasie mówienia. One również decydują o pełniejszej komunikatywności przekazu, uwypuklają stosunek mówiącego do przekazywanych głosem treści, oddają krytyczny charakter wypowiedzi.

Tych kilka uwag ${ }^{17}$ odnosi się do codziennej sytuacji lekcyjnej, kiedy polonista może kontrolować poprawność wymawianiową uczniów podczas krótkich wypowiedzi, prezentacji, przemówień bądź deklamacji. Usterki czy błędy mowy wynikające z przyczyn intelektualnych (złe nawyki, niedbałość, naśladownictwo, afektacja) nie są trudne do usunięcia w toku systematycznych ćwiczeń i stałej kontroli. Mimo konieczności skupiania się na innych działaniach edukacyjnych nie wymagają dodatkowego czasu czy organizowania zajęć pozaszkolnych, choć kulturę żywego słowa w bardzo dużym stopniu podnoszą koła teatralne, koła recytatorskie lub zajęcia pozalekcyjne, realizowane w ramach tzw. godzin karcianych. Ponieważ - jak pisał Tenner - „w żywej mowie dokładność i ścisłość są koniecznym warunkiem piękna”, niezbędne są ćwiczenia doskonalące wymowę i mowę ucznia. „Wolność ducha ludzkiego, która się w mowie objawia, nie powinna przypominać niewoli narzędzi. Wyrazistość i dokładność wymawiania jest wprawdzie warunkiem estetyki; wyrazistość ta nie powinna być jednak dostrzegalna. Piękno zawsze jest wolne i lekkie, jakby samo przez się i dla samego siebie powstałe"18.

Wprowadzenie prawidłowych linii rytmiczno-melodycznych oraz określenie sytuacji akcentuacyjnej w wypowiedzi - to zadanie przeznaczone dla ucznia, którego kształci się na amatora mówienia, czyli miłośnika bez fachowego wykształcenia, chętnego do wykonywania oracji. Podnosząc kompetencje fonetyczno-fonologiczne ucznia, nauczyciel nie tylko realizuje standardy, ale jednocześnie kształci słuch fonemowy, wdraża zasady poprawnej artykulacji, dykcji, akcentu, melodii i rytmu - które uczniowie mogą wykorzystać później w pracy zawodowej. Jeśli będzie ona wymagała umiejętności komunikacji interpersonalnej, odnajdywania się w sytuacjach wymagających autoprezentacji oraz przemawiania przed audytorium, uczniowie już wcześniej wprawią się w swobodnym mówieniu, nauczą budować plan wystąpienia, będą doskonalić użycie prozodemów.

$\mathrm{Na}$ co dzień wzorcową technikę mowy powinien prezentować nauczyciel. Równie ważne jak treść lekcyjnego wykładu są sposób przekazywania wiedzy oraz jakość wypowiedzi:

Przestrzeganie normy wzorcowej jest pożądane we wszystkich kontaktach i rodzajach wypowiedzi, w wypowiedziach o charakterze oficjalnym, zwłaszcza tych, które są wzorcowe i kulturotwórcze, a więc także w wypowiedziach kierowanych do uczniów. Dążenie do osiągnięcia poziomu normy wzorcowej powinno cechować polszczyznę nauczycieli, gdyż na ich zachowaniach językowych wzorują się uczniowie ${ }^{19}$.

Nauczyciel na każdej lekcji pokazuje sposoby i wdraża zasady publicznego mówienia, młodzież zaś nieświadomie przyswaja segmentalny i prozodyczny subkod. Dlatego

\footnotetext{
17 Szerzej o normach wymowy polskiej patrz m.in.: B. Wierzchowska, Wymowa polska, Warszawa 1971; W. Lubaś, S. Urbańczyk, op. cit.; J. Kram, op. cit.; M. Przybysz-Piwko, Fonetyczne podstawy emisji głosu, [w:] Emisja głosu nauczyciela. Wybrane zagadnienia, red. M. Przybysz-Piwko, Warszawa 2006, s. 31-43.

18 J. Tenner, op. cit., s. 110.

19 M. Przybysz-Piwko, op. cit., s. 38.
} 
na wszystkich pedagogach, a szczególnie na poloniście, spoczywa odpowiedzialność za jakość uczniowskich wystąpień. Musi on zwracać uwagę na techniczną sprawność własnych i uczniowskich aktów mowy, ich walory ekspresywno-estetyczne oraz impresyw$n e^{20}$. W efekcie taka dbałość o głosowe wypowiedzi prowadzi do „rozwijania estetycznych i etycznych zachowań wobec języka, rozpoznawania mechanizmów manipulacji językowej, budowania pozytywnie nacechowanych relacji interpersonalnych, poznawania «magii żywego słowa» $[\ldots]^{\prime 21}$, a także kształtowania refleksyjno-krytycznego podejścia do wypowiedzi własnych oraz współrozmówców, co więcej - wyzwala energię kulturotwórczą 22 .

Tożsame cele są zapisane w obowiązujących dla szkół ponadgimnazjalnych standardach, w których zakłada się m.in.: wrażliwość ucznia na błędy wymowy (I 4b), identyfikowanie przez niego cech mówionej odmiany języka polskiego (I 5), perswazji, manipulacji czy etyki językowej, związanej z impresywną i ekspresywną funkcją mowy (I 11; I 11 a i b), znajomość podstawowych pojęć i zasad retorycznych (I 12; II 5), opanowanie kluczowych kompetencji komunikacyjnych, czyli zdolności spostrzegania i kategoryzowania sytuacji społecznej oraz dostosowania do niej sposobu mówienia (I 13; I 13 a i b; I 14; II 2; II 6; II 7; II 8), zgodne z zasadami kompozycji redagowanie dłuższych wypowiedzi ustnych (I 32), uwzględniających dbałość o estetykę wypowiedzi (II 21) 23. Jak widać, scientia recte loquendi, czyli umiejętność zgodnego z normami posługiwania się językiem - to zaledwie jeden z obszarów kształcenia, umieszczony w dokumentach planistyczno-organizacyjnych, ale jakże istotny w edukacji młodych ludzi. Ideałem jest ars bene dicendi (sztuka dobrego mówienia) albo też bene dicendi scientia (właściwe - artystyczne używanie słowa $)^{24}$. Osiągana przez nielicznych, zakłada harmonijne połączenie wiedzy i umiejętności z zakresu: retoryki, estetyki, etyki, erystyki, logiki, gramatyki, historii literatury, teorii literatury, a także kultury języka.

Niestety, studia polonistyczne rzadko opuszczają ludzie oratorsko wykształceni, wyposażeni w warsztat umożliwiający badanie tekstu przed jego prawidłową foniczną realizacją. Rozmowy prowadzone wśród studentów filologii polskiej potwierdzają, że i w szkole zaledwie kilku z nich otrzymało konkretne uwagi dotyczące przygotowania głosowej realizacji wypowiedzi bądź przeprowadziło na lekcji ćwiczenia w tym zakresie. Do tych samych konkluzji doszła Elżbieta Sztankóné-Stryjniak, która zauważyła, że naukę retoryki na studiach polonistycznych zaczyna się praktycznie od podstaw, zwracając szczególną uwagę na estetykę wypowiedzi oraz jej poprawność gramatyczną i stylistyczną, kształcąc umiejętność zabierania głosu oraz prowadzenia dyskusji ${ }^{25}$.

I tu koło się zamyka: próby samodzielnego, intuicyjnego przygotowania wypowiedzi przez nauczyciela, brak umiejętności w zakresie techniki głośnego czytania, techniki mó-

\footnotetext{
20 J. Kram, op. cit., s. 14-15.

${ }_{21}$ M. Latoch-Zielińska, I. Morawska, Kultura żywego słowa $w$ gimnazjum. Między teoriq a praktykq, [w:] Problematyka tekstu głosowo interpretowanego (II), red. K. Lange, W. Sawrycki, P. Tański, Toruń 2006, s. 94.

22 J. Kram, op. cit., s. 212.

23 Informator maturalny..., s. 24, 28-29.

24 H. Lausberg, Retoryka literacka. Podstawy wiedzy o literaturze, tłum., oprac. i wstęp A. Gorzkowski, Bydgoszcz 2002, s. 39.

25 E. Sztankóné-Stryjniak, Miejsce dyskursu retorycznego w procesie kształcenia studentów filologii polskiej, [w:] Współczesna dydaktyka przestrzeniq dialogu i dyskursu, red. J. Bujak-Lechowicz, Piotrków Trybunalski 2009, s. 69-77.
} 
wienia i wygłaszania tekstu-mowy, zaburzenia o charakterze segmentalnym czy suprasegmentalnym sprawiają, że młodzież jest kształcona przez niedostatecznie wyedukowanych oraz niepoprawnie mówiących nauczycieli. Lakoniczne stwierdzenia: „mówisz niepoprawnie”, „mówisz niewyraźnie” „odklepałeś”, „wydukałeś”, sugerują, że uczniowie nie zostali należycie przygotowani do głosowej konkretyzacji tekstów i nie otrzymują właściwej informacji zwrotnej o technice swojego mówienia. Praktyczne działania to część systemu, na który trzeba kłaść duży nacisk. Mają one pomoc uczniowi w stworzeniu i bogaceniu własnego warsztatu pracy, aby w pełni mógł się przygotować do czekającego go egzaminu maturalnego. W celu kształtowania umiejętności potrzebna mu jest strategia, oparta na jego indywidualnych predyspozycjach i poparta próbami, które pomogą wyłonić najbardziej odpowiadającą mu metodę uczenia się, zgodną z typem pamięci i indywidualnymi predyspozycjami.

Doskonalący się przez całe życie nauczyciel może uzupełnić braki wiedzy, jak również doskonalić swoją mowę podczas rehabilitacji, studiów podyplomowych, warsztatów bądź w toku samokształcenia. Obecnie z pomocą polonistom przychodzą standardy kształcenia nauczycieli, przewidujące bloki zajęć z emisji głosu, kultury języka oraz żywego słowa, czasem retoryki. Bogate zaplecze teoretyczne i opanowanie przez nauczyciela podstawowych umiejętności zagwarantuje sukces uczniom, jeśli podczas aktu szkolnej komunikacji pedagog będzie bacznie śledził treść wypowiedzi, jak również sposób mówienia podopiecznych, ich umiejętność radzenia sobie z negatywnymi emocjami i zakotwiczania pozytywnych ${ }^{26}$. Ważne, by niedoskonałości stylistyczno-językowe oraz ortofoniczne uczniów nie przesądzały o ostatecznej ocenie wypowiedzi.

\section{Bibliografia}

Bąk Piotr, Gramatyka języka polskiego, Warszawa: Wiedza Powszechna, 1984.

Bogołębska Barbara, Wygłaszanie przemówień w ujęciu wspótczesnych retoryk praktycznych, [w:] Problematyka tekstu głosowo interpretowanego, red. Katarzyna Lange, Władysław Sawrycki i Paweł Tański, Toruń: Adam Marszałek, 2004.

Demel Genowefa, Minimum logopedyczne nauczyciela przedszkola, Warszawa: WSiP, 1998.

Dittfeld Bożena, Spróbujmy mówić razem. Program profilaktyki logopedycznej (dla przedszkoli, klas kształcenia zintegrowanego i integracyjnego), Kraków: Oficyna Wydawnicza „Impuls”, 2006.

Informator o egzaminie maturalnym z języka polskiego od roku szkolnego 2014/2015, s. 14 www.cke. edu.pl/files/file/Matura-2015/Informatory-2015/Jezyk-polski.pdf [dostęp 14.05.2015].

Kaczmarek Leon, Nasze dziecko uczy się mowy, Lublin: Wydawnictwo Lubelskie, 1977.

Kamińska Dorota, Wspomaganie ptynności mowy dziecka - profilaktyka, diagnoza i terapia jąkania wczesnodziecięcego, Kraków: Oficyna Wydawnicza „Impuls”, 2007.

Kram Jerzy, Zarys kultury żywego stowa, Warszawa: WSiP, 1995.

Kunz Ina, Odkrywanie ciszy - ćwiczenia odprężajace dla dzieci w wieku od 3 do 8 lat, Kielce: Wydawnictwo Jedność, 2000.

26 Por.: E. Minczakiewicz, Mowa - Rozwój-Zaburzenia - Terapia, Kraków 1997; J. Stadnicka, Terapia dzieci muzykq, ruchem i mowq, Warszawa 1998; I. Kunz, Odkrywanie ciszy - ćwiczenia odprężające dla dzieci w wieku od 3 do 8 lat, Kielce 2000. 
Latoch-Zielińska Małgorzata, Morawska Iwona, Kultura żywego stowa w gimnazjum. Między teoria a praktyka, [w:] Problematyka tekstu glosowo interpretowanego (II), red. Katarzyna Lange, Władysław Sawrycki, Paweł Tański,Toruń: Adam Marszałek, 2006.

Lausberg Heinrich, Retoryka literacka. Podstawy wiedzy o literaturze, thum., oprac. i wstęp Albert Gorzkowski, Bydgoszcz: Homini, 2002.

Lubaś Władysław, Urbańczyk Stanisław, Podręczny słownik poprawnej wymowy polskiej, Warszawa: Spółka Wydawniczo-Księgarska, 1990.

Mikuta Marian, Kultura żywego słowa, Warszawa: Państwowe Zakłady Wydawnictw Szkolnych, 1963.

Minczakiewicz Elżbieta, Mowa - Rozwój - Zaburzenia - Terapia, Kraków: Wydawnictwo Naukowe WSP, 1997.

Orr Leonard, Świadomy oddech, tłum. Filip Tarnawski, Katarzyna Czubaj, Łódź: Ravi, 2006.

Przybysz-Piwko Maria, Fonetyczne podstawy emisji głosu, [w: Emisja głosu nauczyciela. Wybrane zagadnienia, red. eadem, Warszawa: Centralny Ośrodek Doskonalenia Nauczycieli, 2006.

Schirner Markus, Techniki oddychania. Techniki wydlużające oddech ( $i$ życie), thum. Monika. Dziedzic, Katowice: Wydawnictwo „Kos”, 2003.

Stownik wymowy polskiej, red. Mieczysław Karaś, Maria Madejowa, Kraków: Państwowe Wydawnictwo Naukowe, 1977.

Stadnicka Janina, Terapia dzieci muzyka, ruchem i mowa, Warszawa: WSiP, 1998.

Szletyńska Zofia, Szletyński Henryk, Prawidłowe mówienie, Warszawa: Ludowa Spółdzielnia Wydawnicza, 1975.

Sztankóné-Stryjniak Elżbieta, Miejsce dyskursu retorycznego w procesie ksztatcenia studentów filologii polskiej, [w:] Wspótczesna dydaktyka przestrzenia dialogu i dyskursu, red. Jolanta BujakLechowicz, Piotrków Trybunalski: Naukowe Wydawnictwo Piotrkowskie, 2009.

Tenner Juliusz, Technika żywego stowa, Lwów: Księgarnia H. Altenberga, 1931.

Wierzchowska Bożena, Wymowa polska, Warszawa: Państwowe Zakłady Wydawnictw Szkolnych, 1971.

Wóycicki Kazimierz, Forma dźwiękowa prozy polskiej i wiersza polskiego, Warszawa: Państwowe Wydawnictwo Naukowe, 1960. 